\title{
PENERAPAN METODE TUTOR SEBAYA UNTUK MENINGKATKAN HASIL BELAJAR PENDIDIKAN AGAMA HINDU SISWA KELAS III SD NEGERI 4 TENGANAN
}

\author{
I MADE SUBAWA \\ SD Negeri 4 Tenganan \\ Email : madebawea@gmail.com
}

\begin{abstract}
ABSTRAK
Penelitian ini dilaksanakan di SD Negeri 4 Tenganan di Kelas III yang kemampuan dan hasil belajar siswanya untuk mata pelajaran Pendidikan Agama Hindu cukup rendah. Tujuan penelitian tindakan kelas ini adalah untuk meningkatkan hasil belajar Pendidikan Agama Hindu pada siswa kelas III tahun pelajaran 2021/2022 melalui penerapan metode Tutor Sebaya. Jenis penelitian ini adalah penelitian tindakan kelas. Penelitian ini menggunakan model Kemmis dan Mc.Taggart. Penelitian ini dilaksanakan dalam dua siklus. Setiap siklus terdapat kegiatan perencanaan, pelaksanaan dan observasi, serta refleksi. Subjek dalam penelitian ini adalah siswa kelas III SD Negeri 4 Tenganan yang berjumlah 13 siswa, terdiri dari 6 siswa laki-laki dan 7 siswa perempuan. Teknik yang digunakan untuk pengumpulan data adalah teknik observasi, dokumentasi dan tes. Instrumen penelitian menggunakan lembar observasi tutor, siswa, guru dan tes tertulis. Teknik analisis data yang digunakan yaitu deskriptif kuantitatif. Data yang dianalisis secara deskriptif kuantitatif adalah hasil belajar. Hasil penelitian ini menunjukkan bahwa dengan penerapan metode tutor sebaya dalam pembelajaran Pendidikan Agama Hindu dapat meningkatkan hasil belajar siswa. Peningkatan hasil belajar siswa tersebut dapat dilihat dari nilai yang diperoleh siswa sebelum dan sesudah dilakukan tindakan. Sebelum dilakukan tindakan, ada 4 siswa atau $30,77 \%$ dari seluruh siswa yang mendapat nilai $\geq 75$. Setelah dilakukan tindakan dengan penerapan metode tutor sebaya Siklus I, hasil tes di siklus I ada 9 siswa atau $69,23 \%$ dari seluruh siswa yang mendapat nilai $\geq 75$. Setelah dilakukan perbaikan dengan mengevaluasi penerapan metode tutor sebaya, dengan cara melaksanakan kuis dan memperbaiki langkah Pendekatan penerapan metode tutor sebaya, terbukti dapat meningkatkan hasil belajar siswa, ditandai ada 13 siswa atau $100 \%$ dari seluruh siswa yang mendapat nilai $\geq 75$. Nilai rata-rata hasil post test yaitu 60,77 meningkat pada siklus I yaitu 80,00 sedangkan pada siklus II yaitu 88,46.
\end{abstract}

Kata Kunci: Hasil Belajar Pendidikan Agama Hindu, penerapan Metode Tutor Sebaya.

\section{ABSTRACT}

This research was carried out at SD Negeri 4 Tenganan in Class III where the ability and learning outcomes of students for Hindu Religious Education subjects were quite low. The purpose of this classroom action research is to improve the learning outcomes of Hindu Religious Education in third grade students in the 2021/2022 academic year through the application of the Peer Tutor method. This type of research is classroom action research. This study uses the Kemmis and Mc.Taggart model. This research was conducted in two cycles. Each cycle contains planning, implementation and observation activities, as well as reflection. The subjects in this study were third grade students of SD Negeri 4 Tenganan, totaling 13 students, consisting of 6 male students and 7 female students. The technique used for data collection is the technique of observation, documentation and tests. The research instrument used observation sheets for tutors, students, teachers and written tests. The data analysis technique used is descriptive quantitative. The data analyzed descriptively quantitatively are learning outcomes. The results of this study indicate that the application of peer tutoring methods in learning Hindu Religious Education can improve student learning outcomes. The increase in student learning outcomes can be seen from the scores obtained by students before and after the action. Before the action was taken, there were 4 students or $30.77 \%$ of all students who got a score of 75 . After the action was carried out with the application of the Cycle I peer 
tutor method, the test results in the first cycle were 9 students or $69.23 \%$ of all students who got a value of 75. After improvements were made by evaluating the application of the peer tutoring method, by conducting quizzes and improving the steps of the approach to the application of the peer tutor method, it was proven to improve student learning outcomes, it was indicated that there were 13 students or $100 \%$ of all students who got a score of 75 . The average value of the post test results is 60.77 , increasing in the first cycle is 80.00 while in the second cycle is 88.46 .

Keywords: Learning Outcomes of Hindu Religious Education, application of the Peer Tutor Method.

\section{PENDAHULUAN}

Pendidikan merupakan bagian yang sangat penting dan tidak dapat dipisahkan dari pembangunan nasional oleh karena itu pembangunan dibidang pendidikan merupakan salah satu upaya meningkatkan sumber daya manusia agar mampu bersaing dalam menghadapi perkembangan zaman. Sesuai dengan pendapat yang diuraikan Ihsan (2008:1) bahwa: "Pendidikan adalah sebagai usaha manusia untuk menumbuhkan dan mengembangkan potensipotensi pembawaan baik jasmani maupun rohani sesuai dengan nilai-nilai yang ada di dalam masyarakat dan kebudayaan". Sejalan dengan itu dalam Undang-undang Republik Indonesia Nomor 20 tahun 2003 menyatakan bahwa pendidikan berfungsi mengembangkan kemampuan dan membentuk watak serta peradaban bangsa yang bermartabat dalam rangka mencerdaskan kehidupan bangsa, bertujuan untuk berkembangnya potensi peserta didik agar menjadi manusia yang beriman dan bertakwa kepada Tuhan Yang Maha Esa, berakhlak mulia, sehat, berilmu, cakap, kreatif, mandiri dan menjadi warga Negara yang demokratis serta bertanggung jawab. (Departemen Pendidikan Republik Indonesia, 2003: 5).

Karena begitu pentingnya bidang pendidikan maka komponen yang terkait dalam dunia pendidikan baik keluarga, masyarakat dan juga pemerintah terus melakukan berbagai upaya untuk meningkatkan kualitas pendidikan.

Meningkatkan kualitas pembelajaran merupakan salah satu hal yang penting yang harus diperhatikan dalam suatu proses belajar mengajar untuk meningkatkan mutu pendidikan. Hal ini merupakan tugas masing-masing sekolah dan yang paling utama adalah guru sebagai tenaga pengajar. Disinilah dituntut kemampuan guru untuk berpikir kreatif dalam melakukan pembelajaran agar siswa lebih mudah memahami materi yang disampaikan dan siswa menjadi antusias dalam mengikuti proses belajar mengajar sehingga pembelajaran yang dilaksanakan berkualitas dan prestasi belajar yang dicapai siswa memuaskan. "Berpikir kreatif berarti menemukan cara-cara baru untuk mengerjakan apa saja" (Schwartz, 1996). Bagi seorang guru, menggunakan strategi pembelajaran tertentu yang relevan yang dapat menciptakan iklim belajar yang kondusif dan mampu meningkatkan hasil belajar siswa yang disesuaikan dengan kondisi siswa, lingkungan kelas, lingkungan sekolah dan budaya dimana sekolah tersebut berada merupakan cara berpikir kreatif. Strategi dalam kaitannya dengan pembelajaran Pendidikan Agama Hindu yang dimaksud adalah siasat atau cara yang sengaja direncanakan oleh guru berkenaan dengan segala persiapan pembelajaran Agama Hindu di kelas.

Seiring dengan perkembangan jaman, guru tidak bisa lagi mempertahankan paradigma lama yaitu guru merupakan pusat belajar di kelas (teacher center). Hal ini kelihatannya masih banyak diterapkan di ruang-ruang kelas dengan alasan pembelajaran seperti ini merupakan pembelajaran yang paling praktis dan tidak menyita waktu, sehingga kurang melatih siswa untuk bersikap kritis, menyebabkan siswa cenderung jenuh, bosan dan akhirnya kurang tertarik terhadap pembelajaran yang berlangsung, hal ini akan berpengaruh terhadap kurang maksimalnya hasil belajar siswa, padahal yang menjadi tolok ukur keberhasilan pendidikan formal adalah hasil belajar yang dicapai siswa.

Hasil belajar merupakan produk dari berbagai faktor, baik faktor dalam maupun faktor luar, sesuai dengan pendapat yang menyatakan bahwa Hasil belajar seorang individu merupakan interaksi antara berbagai faktor yang mempengaruhi baik faktor dalam maupun 
faktor luar individu (Slameto, 2010:54). Oleh karena itu berhasil atau tidaknya suatu proses pembelajaran ditentukan oleh berbagai faktor yang saling berkaitan yaitu antara faktor siswa, guru, kurikulum, sarana, prasarana, metode pembelajaran, lingkungan fisik maupun sosial.

Berdasarkan observasi yang telah dilakukan pada siswa kelas III SD Negeri 4 Tenganan dalam pembelajaran Pendidikan Agama Hindu, guru masih menggunakan metode pembelajaran kovensional yaitu metode ceramah, yakni pembelajaran masih berpusat pada guru (Teacher Center), guru tidak menyadari bahwa metode pembelajaran konvensional yang dilakukan monoton dan membosankan sehingga siswa menjadi kurang antusias, cenderung pasif dan kurang tertarik dalam kegiatan belajar mengajar, sehingga menyebabkan hasil belajar yang dicapai siswa kurang maksimal. Hal tersebut terlihat dari hasil evaluasi sebagian besar masih di bawah Kriteria Ketuntasan Minimal (KKM) yang telah ditetapkan yaitu sebesar 75 . Dari 13 siswa hanya 30,77\% (4 siswa) yang sudah memenuhi KKM, sedangkan 69,23\% (9 siswa), belum memenuhi KKM.

Tidak semua siswa bisa dengan mudah memahami pelajaran yang disampaikan oleh guru. Ada sebagian siswa sudah memahami materi pelajaran dan sebagian lagi belum bisa memahaminya. Adanya perbedaan kepemahaman siswa ini maka terjadi jarak antara yang sudah paham dengan yang belum paham. Hal ini terjadi karena guru lebih sering melakukan pembelajaran secara konvensional yang bersifat monoton sehingga siswa cenderung bosan dengan cara guru mengajarkan berbagai materi pelajaran.

Menyadari permasalahan tersebut, perlu adanya strategi yang tepat dalam pembelajaran Pendidikan Agama Hindu. Karakteristik siswa yang senang bergaul dengan teman sebaya dan bekerjasama sangat tepat bila dilakukan dengan pembelajaran secara kelompok. Salah satunya yaitu dengan menggunakan metode pembelajaran Tutor Sebaya. Metode pembelajaran yang dipilih harus mengutamakan peran siswa dalam pembelajaran dan kerjasama kelompok secara heterogen yang baik tanpa menghilangkan tanggung jawab kepada setiap individu. Metode ini juga dapat menarik perhatian dan meningkatkan semangat belajar siswa. Salah satu metode yang tepat digunakan adalah metode Tutor Seabaya.

Pembelajaran Pendidikan Agama Hindu sering menggunakan beberapa metode. Salah satu metode yang sesuai dengan kondisi siswa kelas III SD Negeri 4 Tenganan adalah metode Tutor Sebaya. Tutor Sebaya adalah seorang atau beberapa orang siswa yang ditunjuk oleh guru sebagai pembantu guru dalam melakukan bimbingan terhadap kawan sekelas (Arikunto, 2006: 11).

Menggunakan metode Tutor sebaya dapat mengakomodasi siswa yang tidak berani bertanya kepada guru tentang materi yang belum dipahaminya. Adanya tutor ini siswa yang belum paham dapat dengan leluasa bertanya kepada tutor yang merupakan temannya sendiri. Berdasarkan uraian di atas, peneliti melakukan Penelitian Tindakan Kelas dengan judul penelitian: "Penerapan Metode Tutor Sebaya Untuk Meningkatkan Hasil Belajar Pendidikan Agama Hindu Siswa Kelas III SD Negeri 4 Tenganan Semester I Tahun Pelajaran 2021/2022".

Tutor sebaya adalah kegiatan belajar siswa dengan memanfaatkan teman sekelas yang mempunyai kemampuan lebih untuk membantu temannya dalam melaksanakan suatu kegiatan atau memahami suatu konsep. Tutor atau ketua kelompok memiliki tugas dan tanggung jawab untuk memberikan tutorial kepada anggota terhadap materi ajar yang sedang dipelajari, mengkoordinir proses diskusi agar berlangsung kreatif dan dinamis, menyampaikan permasalahan kepada guru pembimbing apabila ada materi ajar yang belum dikuasai, melaporkan perkembangan akademis kelompoknya kepada guru pembimbing pada materi yang dipelajari. Peran guru dalam metode tutor sebaya hanyalah sebagai fasilitator dan pembimbing terbatas. Artinya, guru hanya melakukan intervensi ketika betul-betul diperlukan oleh siswa. Fungsi lainnya adalah dengan adanya tutor sebaya siswa yang kurang aktif menjadi aktif karena tidak malu lagi untuk bertanya dan mengeluarkan pendapat secara bebas.

langkah-langkah metode tutor sebaya yang akan dipakai dalam penelitian ini adalah sebagi berikut: 
a. Guru memilih materi yang memungkinkan dapat dipelajari siswa secara mandiri. Materi tersebut dibagi kedalam beberapa sub-sub materi.

b. Guru membagi siswa menjadi kelompok-kelompok kecil sebanyak sub-sub materi yang akan disampaikan guru.

c. Siswa-siswa yang pandai disebar dalam setiap kelompok dan bertindak sebagai tutor sebaya.

d. Masing-masing kelompok diberi tugas mempelajari sub-sub materi setiap kelompok dibantu oleh siswa yang pandai sebagai tutor sebaya.

e. Beri waktu yang cukup untuk persiapan, baik di dalam maupun di luar kelas.

f. Setiap kelompok melalui wakilnya menyampaikan sub materi sesuai dengan tugas yang telah diberikan. Guru bertindak sebagai narasumber utama.

g. Setelah semua kelompok menyampaikan tugasnya secara berurutan sesuai dengan urutan sub materi, beri kesimpulan dan klarifikasi seandainya ada pemahaman siswa yang perlu diluruskan.

Hasil belajar adalah hasil yang dicapai oleh siswa yang telah mengikuti proses belajar mengajar. Hasil pada dasarnya merupakan sesuatu yang diperoleh dari suatu aktivitas, sedangkan belajar merupakan suatu proses yang mengakibatkan perubahan pada individu, yakni perubahan tingkah laku, baik aspek pengetahuannya, keterampilannya, maupun aspek sikapnya.

Pendidikan Agama Hindu adalah suatu ajaran yang membentuk manusia berkepribadian baik (susila) sesuai dengan norma-norma agama yang ada dan selalu berbhakti kepada orang tua, guru, masyarakat, serta kepada Tuhan Yang Maha Esa. Berikut standar kompetensi dan kompetensi dasar yang akan peneliti gunakan dalam penelitian ini.

Tabel 1. Standar Kompetensi dan Kompetensi dasar

\begin{tabular}{|c|c|}
\hline Standar Kompetensi & Kompetensi Dasar \\
\hline $\begin{array}{l}\text { 1. Meyakini manifestasi Sang } \\
\text { Hyang Widhi (Tuhan) } \\
\text { sebagai Tri Purusa. }\end{array}$ & $\begin{array}{l}\text { 1.1 Menguraikan arti Tri Purusa. } \\
\text { 1.2 Menyebutkan bagian-bagian Tri Purusa. }\end{array}$ \\
\hline
\end{tabular}

Hasil belajar Pendidikan Agama Hindu kelas III SD Negeri 4 Tenganan tergolong rendah. Baru sebagian siswa yang dapat mencapai kriteria ketuntasan minimal yaitu 75. Jumlah siswa kelas III sebanyak 13 orang dan yang belum tuntas KKM mencapai 9 siswa. Kurang dari setengah jumlah siswa keseluruhan yang sudah mencapai KKM.

Perlu adanya metode pembelajaran yang dapat memperbaiki hasil belajar siswa kelas III, salah satunya yaitu metode tutor sebaya. Tutor sebaya merupakan metode dimana siswa diajarkan oleh siswa lain yang sudah memahami materi yang diberikan oleh guru. Dengan demikian hasil belajar Pendidikan Agama Hindu dapat ditingkatkan dengan metode pembelajaran tutor sebaya. Bagan kerangka berpikir dapatdilihat dibawah ini.

\section{METODE PENELITIAN}

Penelitian ini dilaksanakan dengan melalui Penelitian Tindakan Kelas (PTK) yang berdaur atau bersiklus. Penelitian ini dilaksanakan di SD Negeri 4 Tenganan yang terletak di Dusun Tenganan Dauh Tukad, Desa Tenganan, Kecamatan Manggis, Kabupaten Karangasem. Jumlah subjek dalam penelitian ini sebanyak 13 anak terdiri dari 6 orang siswa laki-laki dan 7 orang siswa perempuan. Penelitian ini dilakukan mulai dari bulan Juli 2021 sampai dengan bulan September 2021.

Prosedur penelitian yang digunakan pada penelitian ini menggunakan model mengacu pada gagasan Kemmis dan Taggart (dalam Kasbuloh, 2005: 63). Secara umum pelaksanaan 
dilaksanakan dalam dua siklus, pada setiap siklus diadakan dua pertemuan dengan tindakan tertentu. Tindakan-tindakan yang dimaksud adalah berupa perencanaan tindakan, pelaksanaan tindakan, observasi dan refleksi. Pada perencanaan tindakan dilakukan pembuatan perangkat pembelajaran dalam bentuk Rencana Pelaksanaan Pembelajaran (RPP) yang didalamnya terdapat langkah-langkah penerapan metode tutor sebaya, dan instrumen penelitian.

Pada tahap perencanaan setiap siklusnya, peneliti membuat setiap pertemuan dengan satu RPP, sehingga dalam satu siklus ada 2 buah RPP yang peneliti buat, selain RPP peneliti juga membuat lembar observasi untuk observer, menyiapkan soal tes pretest dan juga postest, sebagai data pendukung, peneliti juga menyiapkan kamera untuk dokumentasi. Pada tahap pelaksanaan, peneliti melaksanakan pembelajaran dengan menggunakan metode tutor sebaya seperti yang telah direncanakan pada RPP. Kegiatan observasi dilakukan oleh teman sejawat peneliti dengan mengisi lembar observasi yang telah disediakan oleh peneliti. Observasi digunakan oleh peneliti untuk mengetahui sampai sejauhmana pembelajaran yang telah dilaksanakan oleh peneliti. Untuk refleksi digunakan oleh peneliti untuk mengetahui kekurangan-kekurangan yang terjadi selama proses belajar-mengajar, sehingga dengan adanya refleksi peneliti bisa memperbaiki kekurangan yang ada agar pertemuan selanjutnya bisa lebih baik lagi.

Sumber data berasal dari siswa, guru/ peneliti, teman sejawat/ observer dan dokumen. Tekhnik pengumpulan data adalah dengan observasi, dokumentasi dan hasil tes atau hasil belajar siswa. Sedangkan untuk validitas data menggunakan tekhnik triangulasi data dengan melibatkan siswa, guru, dan teman sejawat. Analisis data pada penelitian ini dilakukan secara kuantitaif maupun kualitatif. Data yang diperoleh dari hasil tes dianalisis secara kuantitatif berdasarkan persentase, sedangkan data yang diperoleh dari hasil observasi dianalisis secara kualitatif.

Metode pembelajaran tutor sebaya dikatakan dapat meningkatkan hasil belajar Pendidikan Agama Hindu pada siswa kelas III SD Negeri 4 Tenganan apabila 75\% dari jumlah siswa minimal sudah mendapatkan nilai 75 .

\section{HASIL DAN PEMBAHASAN}

\section{Hasil Penelitian}

Hasil dalam penelitian ini menunjukkan bahwa adanya peningkatan hasil belajar siswa kelas III SD Negeri 4 Tenganan dalam pembelajaran Pendidikan Agama Hindu tahun pelajaran 2021/2022 setelah diterapkan pembelajaran tutor sebaya. hasil belajar tersebut dapat dilihat pada tabel berikut.

Tabel 2. Rekapitulasi Prestasi Belajar Siswa

\begin{tabular}{|l|l|c|c|c|}
\hline NO & \multicolumn{1}{|c|}{ URAIAN } & $\begin{array}{c}\text { REFLEKSI } \\
\text { AWAL }\end{array}$ & $\begin{array}{c}\text { SIKLUS } \\
\text { I }\end{array}$ & $\begin{array}{c}\text { SIKLUS } \\
\text { II }\end{array}$ \\
\hline 1 & Nilai Rata-rata & 60,77 & 80,00 & 88,46 \\
\hline 2 & Daya Serap & $60,77 \%$ & $80,00 \%$ & $88,46 \%$ \\
\hline 3 & Jumlah Siswa Belum Tuntas & 9 & 4 & 0 \\
\hline 4 & Jumlah Siswa Tuntas & 4 & 9 & 13 \\
\hline 5 & Persentase Ketuntasan Belajar & $30,77 \%$ & $69,23 \%$ & $100 \%$ \\
\hline
\end{tabular}




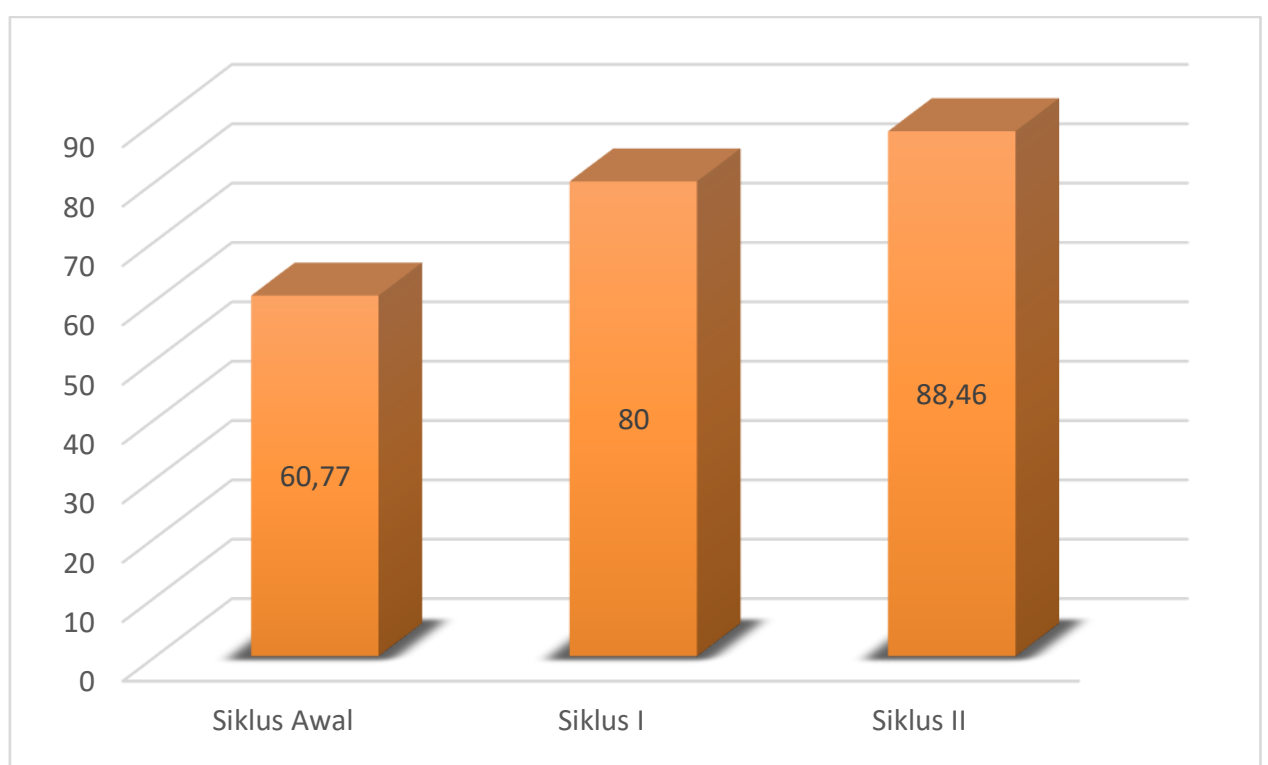

Gambar 1. Hasil Nilai Rata Rata Tiap Siklus

\section{Pembahasan}

Berdasarkan hasil penelitian yang telah dijelaskan di atas, bahwa hasil belajar Pendidikan Agama Hindu yang diperoleh siswa kelas III SD Negeri 4 Tenganan terjadi peningkatan pada setiap siklus setelah diterapkan metode pembelajaran tutor sebaya dan akhirnya lebih dari $75 \%$ jumlah siswa mencapai KKM. Maka teori yang dikemukakan oleh Made Wana (2009: 3) terbukti bahwa pemilihan dan penggunaan strategi pembelajaran yang tepat dalam kegiatan pembelajaran sangat perlu karena untuk mempermudah proses pembelajaran sehingga dapat mencapai hasil belajar yang optimal.

Metode tutor sebaya dapat terlaksana dengan baik dan bisa mencapai tujuan yang diharapkan tergantung siswa yang menjadi tutornya. Tutor disini berperan sebagai pengganti guru dalam membantu temannya memahami pelajaran. Guru telah memilih siswa menjadi tutor dengan kriteria siswa tersebut menguasai materi yang diajarkan serta memiliki hubungan emosional yang baik dan bersahabat dengan siswa yang lain. Untuk menentukan siswa yang menjadi tutor perlu mempertimbangkan beberapa hal sebagai berikut menguasai bahan yang akan disampaikan atau ditutorkan, mengetahui cara mengajarkan bahan tersebut, memiliki hubungan emosional yang baik, bersahabat dan menjunjung situasi tutoring, siswa yang berprestasi akan lebih menunjang pelajaran dengan metode ini karena siswa yang menjadi tutor tersebut lebih mempunyai kepercayaan diri.

Setelah melaksanakan langkah-langkah dari tutor sebaya terlihat terjadi peningkatan dari nilai rata-rata siswa dan jumlah siswa yang telah mencapai ketuntasan semakin banyak. Hal ini sesuai dengan teori dari Sukmadinata (2007) bahwa menggunakan metode tutor sebaya dapat membuat siswa yang kurang paham tentang materi pelajaran berani bercerita kepada temannya yang menjadi tutor sehingga kesulitan tersebut dapat diatasi pada akhirnya hasil belajar siswa dapat meningkat.

Pada siklus II terjadi peningkatan hasil belajar dari pra tindakan dan siklus I. Terjadinya peningkatan hasil belajar pada siklus II ini dikarenakan ada sedikit modifikasi dalam langkahlangkah pembelajaran yaitu, guru mengamati seluruh siswa dan mengarahkan siswa yang hanya diam saja tidak memperhatikan tutor untuk ikut bertanya materi yang belum diketahui atau ikut menanggapi pernyataan dari teman kelompoknya. Oleh karena itu, pada penelitian ini siswa yang mendapatkan nilai $\geq 75$ mencapai kriteria keberhasilan yaitu $\geq 75 \%$, sehingga penelitian ini dikatakan berhasil dan di hentikan pada siklus II.

\section{KESIMPULAN}

Berdasarkan uraian pada bagian sebelumnya, dalam penelitian ini dapat ditarik simpulan sebagai berikut. Penerapan metode tutor sebaya dapat meningkatkan hasil belajar 
Pendidikan Agama Hindu siswa kelas III SD Negeri 4 Tenganan tahun pelajaran 2021/2022. Hasil tersebut dapat dilihat dari nilai rata-rata, daya serap, dan ketuntasan belajarnya. Pada refleksi awal nilai rata-rata siswa adalah 60,77 menjadi 80,00 pada siklus I dan pada siklus II menjadi 88,46. Demikian pula halnya dengan daya serap siswa. Pada refleksi awal daya serap siswa adalah $60,77 \%$ menjadi $80,00 \%$ pada siklus I dan pada siklus II menjadi $88,46 \%$. Sementara itu, ketuntasan klasikal siswa pada refleksi awal sebesar 30,77\%, pada siklus I sebesar $69,23 \%$ dan pada siklus II menjadi $100 \%$.

\section{DAFTAR PUSTAKA}

Departemen Pendidikan RI. 2003. Sistem Pendidikan Nasional, UU No 20. Jakarta: Depdiknas. Ihsan, H, F. 2008. Dasar-dasar Pendidikan. Jakarta: PT Rineka Cipta.

Made Wana. (2009). Strategi pembelajaran inovatif Kontemporer. Jakarta: Bumi Aksara. Sedarmayanti., dan H. Syarifudin. 2002. Metodologi penelitian. Bandung : Mandar maju. Slameto. 2010. Belajar dan Faktor-faktor Yang Mempengaruhinya. Jakarta: Rineka Cipta.

Sukmadinata, Nana Syaodih. (2007). Metode Penelitian Pendidikan. Bandung: PT. Remaja Rosdakarya Offset 